\title{
Representações do Pavilhão da Alemanha de Mies van der Rohe, 1929
}

Representations of the German Pavilion by Mies van der Rohe, 1929

Fernando Guillermo Vazquez Ramos*

${ }^{*}$ Coordenador e professor do Programa de Pós-Graduação em Arquitetura e Urbanismo da Universidade São Judas Tadeu. Doutor em Arquitetura (Universidad Politécnica de Madrid, 1992); Master em Estética y Teoria de las Artes (Instituto de Estética y Teoria de las Artes, 1990); Técnico em Urbanismo (Instituto Nacional de Administración Pública, 1988); Arquiteto (Universidad Nacional de Buenos Aires, 1979). Coordenador do Núcleo DocomomoSP.

ORCID:0000-0003-3472-5598

\section{(cc) (i) (8)}

Recebido: $24 / 05 / 2020$

Aceito: $16 / 06 / 2020$

https://doi.org/10.37916/arq.urb.v28i.438

\section{Resumo}

O artigo discute o Pavilhão da Alemanha, obra de Mies van der Rohe, projetado e construído para a Exposição Internacional de Barcelona, de 1929. Especificamente, analisa e reflete sobre possibilidades interpretativas que as representações fotográficas oficiais do pavilhão têm oferecido desde sua divulgação, seja a partir de comentários de especialistas e historiadores (que as comentam até nossos dias), seja sob novas óticas (a da lógica visual, por exemplo), relativas às representações gráficas (principalmente a da perspectiva) e a sua influência na construção das imagens de divulgação do conhecido edifício, assim como de sua percepção significativa e expressiva, que há décadas vem sendo mediada por essas imagens.

Palavras-chave: Representação da arquitetura. Fotografia. Perspectiva gráfica. Lógica visual. Arquitetura Moderna.

\section{Abstract}

The Article is about the German Pavilion, an oeuvre by Mies van der Rohe, designed and built for the 1929 Barcelona International Exhibition. In specific terms analyzes (and think about) the interpretative possibilities that the official photographic representations of the pavilion offered at the time of their circulation, both from the comments of experts and historians (who comment on them until today), as well as from a new approach (that of visual logic, for example) related to graphic representations (mainly that of perspective) and their influence in the construction of the publicity images of the well-known building, as well as its significant and expressive perception, which has been mediated by these photographs for decades.

Keywords: Architectural representation. Photography. Graphic Perspective. Visual logic. Modern Architecture. 


\section{Introdução}

$\begin{array}{lll}\text { 1. É difícil saber exatamente qual } & \text { 2. A fotografia foi bastante divul- }\end{array}$ foi a participação efetiva de Lilly gada na época; por exemplo, Reich no desenho do pavilhão, nas revistas alemãs Das Neue porque sua expertise e seu gran- Berlin (DEUTSCHLAND IN BARCELONA, 1929, p. 188) e de reconhecimente Die Form (BIER, 1929, p. 427) e onal nos círculos cultos e de es- na francesa Cahiers d'Art (RUpecialistas - tanto de Weimar BIÓ I TUDURI, 1929, p. 408). como de Berlim - eram pela Alguns autores, como Wolf montagem de exposições. Como Tegethoff, as atribuem ao foa $16 \mathrm{mil} \mathrm{m}^{2}$ distri- tografo russo Sacha Stone (DODDS, 2005, p. 52), o que buídos em oito prédios para orga- provável, pois Stone era próxnizar e apresentar seus produtos, imo ao grupo entorno da revista devemos supor que sua dedica- "G". (MERTINS; JENNINGS, ção terá se concentrado antes 2010, p. 248)

nessa tarefa que na do edifício do 3.0 pavilhão foi finalizado e in pavilhão. Ainda assim, não há augurado em 27 de maio de como esquecer, como sublinham 1929, e a foto apareceu na vários autores - entre eles, Laura mesmo ano A revista At Martínez de Guereñu (2018, p. mava ser publicada em julho 47 traducão nossa) - que a co- de modo que é muito prováve missão foi "aceta [por Mies] em que a imagem tenha sido missão foi "aceita [por Mies] em que ina
parceria com Lilly Reich" ("under- 10 mada entre maio e junho de take in partnership with Lilly Re- Die Form, que foi publicada em ich"). O sítio oficial da Bauhaus, que comemora os 100 anos da escola (BAUHAUS100, [s.d.]), também testemunha a estreita colaboração entre os dois artistas a partir de 1926. A associação terminou praticamente em 1938 como aponta Franz Schulze (1986, p. 222), quando o arquiteto migrou para os EUA, embora Reich continuasse cuidando de seu escritório em Berlim até fins da Guerra Mundial. Para mais dados sobre essa relação profissional, ver Christiane Lange (2006)

usjt • arq.urb • número 28 | maio - agosto de 2020
0 arquiteto, crítico e curador espanhol Juan José Lahuerta (2015) chamou atenção para algumas questões relativas às imagens fotográficas do Pavilhão da Alemanha, construído na Exposição Internacional de Barcelona de 1929, obra de Ludwig Mies van der Rohe, que contou com a colaboração da gestalter Lilly Reich. ${ }^{1}$ Ainda que Lahuerta não tenha sido o primeiro a adentrar esse tipo de pesquisa (BONTA, 1977; TEGETHOFF, 1989; QUETGLAS, 1991, 2001; NEUMEYER, 1995; ROVIRA, 2002; DODDS, 2005), seus comentários sugerem novas interpretações e leituras para um tema sempre instigante: o das representações.

Lahuerta se detém numa imagem em particular, uma foto da divulgação oficial do pavilhão produzida pela Berliner Bild-Bericht, ${ }^{2}$ onde se vê o edifício, cedo, numa manhã ensolarada do fim da primavera de 1929, provavelmente em junho. ${ }^{3}$ A imagem oferece, em sua plenitude, a vista completa da fachada nordeste, a mais longa e interessante do edifício. Ao centro, destaca-se a escada de acesso ao pódio, onde está propriamente o pavilhão (Figura 1).

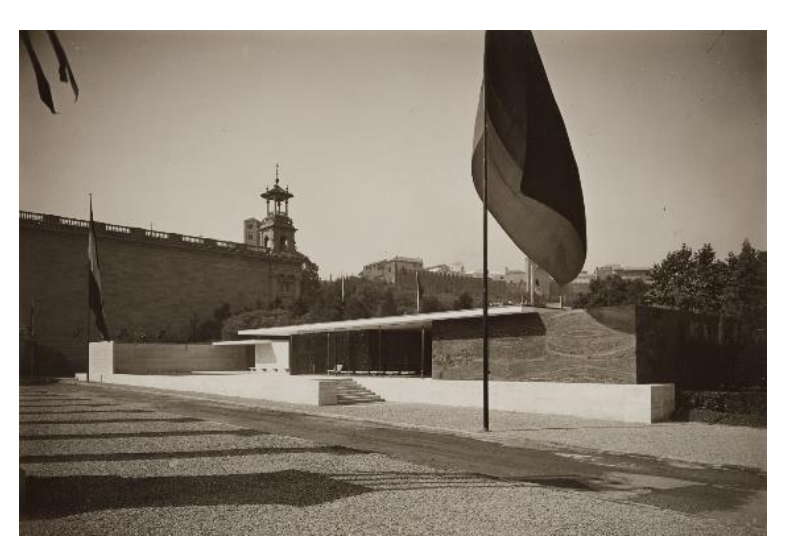

Figura 1. Vista da fachada principal (nordeste), a partir do norte. Pavilhão da Alemanha. Exposição Internacional de Barcelona, 1929. Berliner Bild-Bericht. Fonte: Justus Bier (1929, p. 427)

Como acontece com a maioria das fotografias da divulgação oficial, ${ }^{4}$ uma das, se não a mais, ${ }^{5}$ reproduzida posteriormente apresenta o edifício sem nenhuma presença humana, limpo e exuberante, embora sem escala ou referência. Apresenta-se descortinado, ${ }^{6}$ mas pouco conseguimos ver do interior, apesar das grandes vidraças transparentes da fachada: apenas, uma poltrona e cinco otomanas ${ }^{7}$ posicionadas de uma forma incomum - enfileiradas contra a parede de vidro da fachada. 
pelo menos numa das duas edições sobre a reconstrução do pavilhão: El pabellón Alemán de Barcelona de Mies van der Rohe, 1929-1986 (TORRENT, 1987, p. 48-51) e Mies van der Rohe: el Pabellón de BarceIona (SOLÀ-MORALES; CIRICl RAMOS, 1993, p. 21-24). Para uma explicação mais aprofundada sobre este material fotográfico ver a meticulosa pesquisa realizada por George Dodds (2005) que situa grande parte das imagens produzidas sobre o pavilhão.

5. Desde a célebre monografia de Philip C. Johnson (1947, p. 67) até o último grande livro sobre Mies van de Rohe, o de Detlef Mertins (2014 p. 141), tem sido a imagem paradigmática do pavilhão.

6. Faziam parte do arranio interior do pavilhão pesadas cortinas de veludo vermelho, que compunham com um tapete de lã preta e com a parede de ônix dourado, uma alegoria à bandeira da Alemanha da República de Weimar, que tinha essas cores.

7. Tanto a "poltrona Barcelona" como a "otomana Barcelona" foram desenhadas por Mies van der Rohe corialme para especialmente para o 1929. A patente foi apresentada en 7 de novembro desse ano (LANGE, 2006, p. 174).

8. "La penumbra creciente hacia el interior, en contraste con la sorprendente luminosidad del exterior" (PLATZ, Gustav Adolf. Die Baukunst der neusten Zeit. 2. ed. Ber-lim: Propyläen, 1930). Im-portantes críticos da atuali-dade, como Wolf Tegethoff $(1985,1989)$, têm reiterado essa interpretação.

9. Tegethoff se refere aos vidros que tinham cloro na composição, produzidos à época pela indústria alemã, mas que, por questão de salubridade, deixaram de ser fabrica- dos nos anos 1960. O edifício reconstruí-do em Barcelona em 1986 não tem esse tipo de vidro e, portanto, seu interior é bem mais luminoso que o do origi-

10. Não se sabe qual era o pédireito do edifício, pois a documentação se perdeu durante guerra. Mas exis-te um corte desenhado de memória por Sergius Rue-genberg (ajudante de Mies no fim dos anos 1920), pu-blicado em Architectura Monograph (MIES VAN DER ROHE, 1986, p. 69), que sugere aproximada-mente $3,10 \mathrm{~m}$. Foi essa a base para definir a altura do edifício na reconstrução de 1986 (que adotou 3,106 m).

11. Goday i Casals, que também era historiador da arte, foi o projetista do Pavilhão Cidade de Barcelnăo da mesma exposição. Este se enmesma exposição. Este se enoposta da Plaza de los Bellos oposta da Plaza de los Bellos nem o pavilhão da cidade de nem o pavilhão da cidade de da Plaza de los Bellos Ofícios; o conjunto foi demolido depois da exposição, e a praça perdeu o belo nome.

12. Uma importante atração da feira que, com seus jogos de uzes e água, juntava visitantes

13. Eisenstein já havia sido mencionado por Quetglas (2001, p. 1757-159) trais cristais refletores. O cálido vento balança levemente as enormes bandeiras alemãs que flanqueiam a construção. Os mastros, onde os tecidos ondeiam, impõem sua verticalidade num primeiro plano contundente, realçando a horizontalidade do edifício justamente pela evidente contraposição das linhas horizontais que o dominam, assentado no longitudinal pódio.
Pouco mais podemos ver, pois, como já se afirma- Mas a análise de Lahuerta se detém nas sombras va nas publicações dos anos 1930, o edifício tem sempre "a penumbra crescendo para o interior, em contraste com a luminosidade do exterior" (PLATZ ${ }^{8}$ apud BONTA, 1977, p. 163, tradução nossa). Esse efeito se deve não só aos grandes "vidros com tingimento verde-escuro", como já mencionara Wolf Tegethoff (1989, p. 84), ${ }^{9}$ que formam a parede do lado do pátio interior, dando-lhe uma atmosfera especial, mas também ao enorme carpete preto de lã, que cobre grande parte do piso interno, e às paredes, de mármore verde de Tinos (no corredor de acesso) e de ônix dourado do Marrocos (que se ergue no meio da sala principal, ocupando todo o pédireito $^{10}$ e com 5,80 $\mathrm{m}$ de largura). Embora polidas (brilhantes), essas paredes não competiam com as superfícies opacas, pois a luz que refletiam era rapidamente absorvida pelo piso de travertino e o estuque do forro.

A ligeira construção parece imperturbável, exposta ao vento primaveril que sopra do Mediterrâneo acariciando seus pétreos muros claros e seus espec- projetadas sobre o pavimento, que aparecem em primeiro plano da imagem, ainda mais próximo do observador que os mastros e suas bandeiras. Essas formas fantasmagóricas, como gosta de chamá-las o próprio autor, eram produzidas por algumas das oito colunas jônicas e por um dos dois pedestais para bandeiras, que faziam parte do projeto do arquiteto novecentista catalão José Goday i Casals ${ }^{11}$ propostos para cercar ou delimitar a Plaza de los Bellos Ofícios, onde se encontrava a Fuente Mágica, ${ }^{12}$ justamente em frente ao pavilhão. Outros autores também se ocuparam dessas sombras por exemplo, Quetglas (1991) e Rovira (2002) -, mas Lahuerta o faz com referência na própria fotografia.

A fotografia é o que é moderno aqui, pois usa um recurso inovador na época, muito apreciado também pelos amadores, pelo qual o fotógrafo deixa deslizar sua própria sombra no quadro da imagem. É uma forma indireta e eficaz de incluir na janela da imagem, como uma assinatura, a silhueta do próprio autor, mas também o mundo circundante, as referências técnicas (da prática fotográfica) e os alardes vanguardistas (do fotógrafo). O crítico espanhol conta como essa prática afetou pintores como Pierre-Auguste Renoir (Le Pont des Arts, 1867-68) e diretores de cinema como Serguei Eisenstein (Bronenosets Potyomkin, 1925), ${ }^{13}$ mostrando a disseminação da ideia em outras artes, a partir da rápida popularização da prática fotográfica, entre outras 


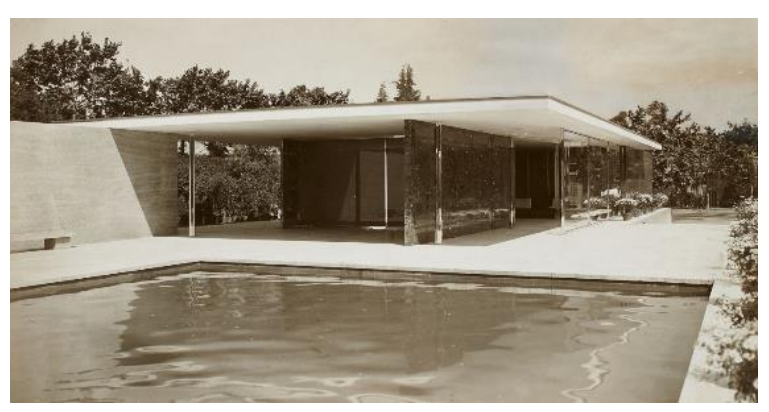

Figura 2. Vista da construção principal, a partir do leste, sobre o pódio. Pavilhão da Alemanha. Exposição Internacional de Barcelona, 1929. Imagem manipulada. Fonte: Justus Bier (1929, p. 427).

\begin{abstract}
14. A popularização começou na Alemanha, sede da fábrica de Leitz Wetzlar, que produziu a câmera Leica, a que se somaram a Zeiss Ikon de Carl Zeiss e, a partir de 1929, a Rolleiflex, fabricada pela firma Franke \& Heidecke, entre outras.

15. Mencionamos aqui a Bauhaus porque Mies van der Rohe era à época um de seus respeitados professores (e chegaria a dirigi-la em 1930).

16. Seguramente, a segunda imagem mais publicada do pavilhão.

17. As portas eram retiradas duran te o dia para permitir o acesso livre dos visitantes, mas também como demonstração contundente da integração interior-exterior promovida pela arquitetura do pavilhão.

18. Ainda que não possamos determinar a autoria da manipulação, neste artigo, entenderemos que todas as imagens manipuladas tiveram a anuência de Mies van der Rohe e formam parte da divulgação oficial do pavilhão promovida pelo arquiteto.
\end{abstract}

usjt • arq.urb • número 28 | maio - agosto de 2020 coisas, graças à ampla comercialização da câmera portátil Leica, criada pelo alemão Oskar Barnack em $1925 .^{14}$

Um ponto importante sobre esse tema se refere à Bauhaus, ${ }^{15}$ que demorou a desenvolver oficialmente a fotografia como disciplina. A escola vanguardista estava bastante atrasada nesse assunto, pois só em 1929 incluiria uma oficina de fotografia (a de Walter Peterhans) (WARE, 1999, p. 506). Embora seus alunos - mas não os professores - a utilizassem largamente, antes como registro que como recurso expressivo, nas propostas da publicidade, ou de apresentação de produtos da instituição, era "recorrente [o] sublinhado do contraste entre tons claros e escuros" (WARE, 1999, p. 518). As sombras, na imagem que analisamos, teriam esse efeito. Em qualquer caso, não parece estranho que as sombras tenham sido incorporadas a essa imagem, ainda que os fotógrafos da Berliner Bild-Bericht não tenham sido contratados por sua ousadia ou seu vanguardismo, mas pela reconhecida experiência, qualidade técnica e precisão.

Lahuerta não se pergunta o porquê de essas sombras permanecerem nessa fotografia em particular, mas a pergunta seria pertinente, uma vez que sabemos que muitas imagens desse tipo foram retocadas para eliminar objetos e efeitos não desejados ou considerados inadequados a uma imagem que se queria apresentar ou um produto que se queira vender.
Temos um bom exemplo do grau de alteração a que se podia submeter o material fotográfico do pavilhão em outra imagem da divulgação oficial, ${ }^{16}$ também produzida pela equipe da Berliner Bild-Bericht. Trata-se da fotografia tomada a partir do grande espelho d'água do pátio externo (Figura 2), que ocupa o lado sudeste da construção, mostrando o edifício principal. Sob a grande cobertura plana, destacamse o acesso franco (sem portas), ${ }^{17}$ as leves colunas cromadas e a parede revestida com mármore verde de Tinos. No interior do edifício, percebe-se nitidamente a penumbra do salão principal com as poltronas Barcelona sobre o tapete preto de lã.

Evidentemente, não se trata de um documento de registro notarial, mas de uma imagem de divulgação, que, apesar disso, poderia retratar a realidade física do que se vê, ainda assim, foi manipulada ${ }^{18}$ (como se percebe quando se a compara com a imagem da Figura 3), eliminando-se um vestígio do entorno que prejudicava a leitura diáfana da construção. À época, ninguém se importou com a alteração, e a imagem foi publicada sem nenhum comentário a respeito. E continuou sendo usada com muito êxito, pois, desde a icônica monografia de Philip C. Johnson (1947, p. 69) sobre Mies van der Rohe, que serviu de catálogo para sua primeira grande exposição nos EUA, passando pelo prestigioso catálogo da exposição retrospectiva sobre o arquiteto realizada pelo Art Institut of Chicago em 1968, um ano antes do falecimento de Mies, e assinado por A. James Speyer (1968, p. 45), até o extenso trabalho 


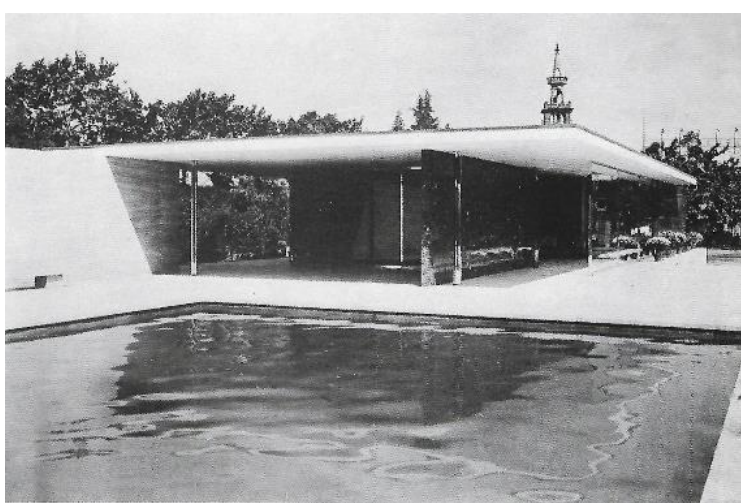

Figura 3. Vista da construção principal, a partir do leste, sobre o pódio. Pavilhão da Alemanha. Exposição Internacional de Barcelona, 1929. Note-se a ponta da torre da fábrica Casaramona por cima da cobertura do pavilhão. Coleção Hedrich-Blessing. Fonte: Hilberseimer (1984, p. 143).

19. Um dado curioso, no caso de Juan Pablo Bonta (1977, p. 221), que analisou justamente essa fotografia, é que, no seu famoso livro, a imagem está invertida.

20. Ainda que também tenham se baseado em plantas idealizadas, pois não havia originais, outros autores, além de Bonta (1977), se debrucaram sobre o significado e a importância das imagens fotográficas; entância das imagens fotográficas; en-
tre eles, Dodds (2005), Neumeye (1995), Quetglas (1991), Rovira (2002), Tegethoff (1989) e até o próprio Franz Schulze (1986)

21. A "regra dos terços" é uma técnica fotográfica segundo a qual devese imaginar a imagem dividida em 9 quadrados (traçando 2 horizontais e 2 verticais imaginárias) e posicionar nos pontos de cruzamento dessas linhas o tema que se deseja destacar. Nesse caso, é a torre no terço superior direito.

22. Ignasi de Solà-Morales Rubió (1994, p. 153, tradução nossa) afir-

mou que: "falar em contexto no trabalho de Mies é introduzir outro paradigma conceitual inadequado e inapropriado. Suas obras de arquitetura não foram produzidas em relação ao contexto, nem constituíram como comentário ou mimese do lugar onde estavam" ("to speak of context in the work of Mies is to introduce another inadequate, inappropriate conceptual paradigm. His works of architecture were not produced in relation to the context, nor did they constitute a commentary on, or mimesis of, the place in which they were situated"). A alteração das imagens fotográfica parece confirmá-lo.

23. Ou seja, não são do lote de fotografias da divulgacão oficia do pavilhão. Dirigida por Ken do pavilhão. Dirigida por Ken pecializada em arquitetura pecializada em arquitetura, ta em Chicago em 1929. reflexivo de Peter Carter (1999, p. 25), Mies van der Rohe at work, de 1974, essa imagem perpetua a ideia do isolamento do pavilhão como peça etérea que pode estar em qualquer lugar.

Foi só no fim dos anos 1970, quando o arquiteto e crítico argentino Juan Pablo Bonta (1977) chamou atenção para o tema, que se iniciou uma análise mais aprofundada do material fotográfico existente,$^{19}$ único sobre o qual críticos e historiadores teceram elucubrações e interpretações variadas, desde 1930 até a reconstrução do pavilhão, em $1986 .{ }^{20} \mathrm{~A}$ imagem não manipulada (Figura 3 ) permite ver a ponta de uma torre acima da cobertura do pavilhão, nada menos que no terço superior direito. ${ }^{21} \mathrm{~A}$ torre é da fábrica Casaramona, de 1909, obra art nouveau de nada menos que um dos principais representantes do modernisme catalá, Josep Puig i Cadafalch. A curiosa construção aparece por cima da cobertura do pavilhão, criando um ruído visual que, imaginamos, foi considerado inadequado pelo arquiteto e, por isso, apagado. ${ }^{22}$ Mas a torre, muito conhecida em Barcleona, era uma referência importante da localização do pavilhão na cidade. Situava o edifício num lugar específico e lhe dava uma pertinência ambiental precisa. Ainda mais, colocava o arquiteto alemão num diálogo, improvável mas muito interessante, com um respeitado arquiteto local, vinculando - de forma não deliberada, claro uma obra do modernisme com uma do movimento moderno.
Contudo, tampouco essa imagem (a da Figura 3) é impoluta. Veja-se que o novo enquadramento elimina os vasos floridos que estavam à direita do espeIho d'água, sobre a borda do pódio. É certo que na foto anterior (Figura 2) já se percebia essa intenção (as plantas aparecem cortadas, e não se mostra a borda do pódio), mas elas estão ali. Podemos supor, com alguma certeza, que Mies van der Rohe não devia tolerar esses vasos com suas flores e o ambiente bucólico e festivo que insinuavam. Uma decoração sem sentido para um edifício que pretendia mostrar a grandeza da nova arquitetura (e da industria alemã, claro). Uma prova cabal desse entendimento é que vasos e flores foram retirados para tirar a foto da fachada nordeste (Figura 1), ainda que provavelmente tenham depois sido repostas, como testemunha a (Figura 2).

Embora menos, essa imagem (Figura 3) também circulou em publicações especializadas. Por exemplo, no número monográfico sobre a obra de Mies van der Rohe da revista francesa L'Architecture d'Aujurd'hui (MIES VAN DER ROHE, 1958, p. 13) e também no livro sobre $\mathrm{o}$ arquiteto que o urbanista Ludwig Hilberseimer (1984, p. 143) publicou em 1956. Ambas provêm da mesma fonte: a coleção da empresa de fotógrafos Hedrich-Blessing, de Chicago. ${ }^{23}$ Provavelmente, se tivessem pedido ao arquiteto uma imagem do pavilhão como essa que Mies possuía, como vimos, ele teria oferecido a retocada. Ainda, interessa saber que tanto L'Architecture d'Aujourd'hui como Hilberseimer poderiam ter 


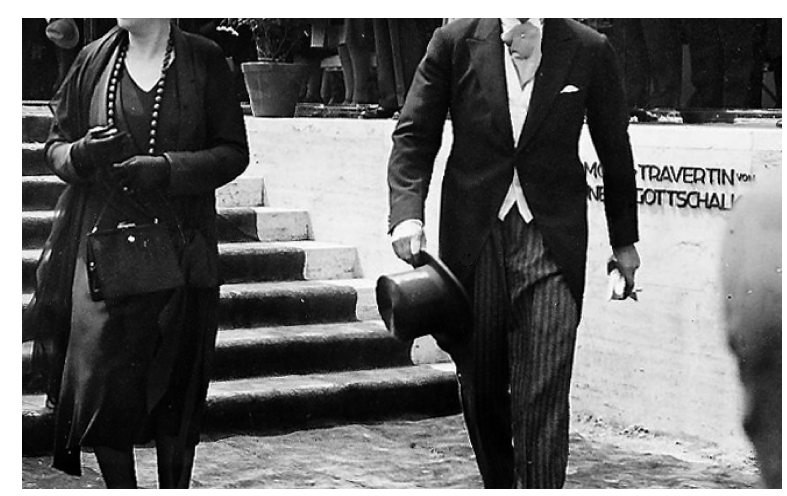

Figura 4. Detalhe de foto do dia da inauguração do pavilhão. Atrás do Reichskommissar, parte do letreiro da empresa Köstner \& Gottschalk, fornecedora dos mármores. Fotografia de Gabriel Casas i Galobardes. Fonte: Guereñu (2018, p. 53). 24. O livro de A. James Speyer 28. "Mies tended to control photog$(1968$, p. 45) publica a imagem mani- raphy after the fact, through editing pulada indicando nos créditos que and altering prints". Ainda que ela pertencia à coleção da empresa frase seja do fotógrafo Hedrich-Blessing. de Mies van der Rohe à publi25. Referimo-nos a Groszstadt Archi- cação das fotos do Seagram Build25. Refermo-nos a Groszstadt Arch- cação das fotos do Seagram Buildtektur, de 1927. Em "The Art of Archi- ing, portanto, no fim dos anos tecture", afirmou que: "A arquitetura, 1950, o controle sobre o materia mesmo nos niveis mais altos, é sem- quiteto tinha já essa disposição pre determinada pela sociedade que (ou indisposição) para com a foviabiliza sua criação e pelos meios tografia no fim dos anos 1920 .

materiais disponiveis" ("Architecture, 29. "Inscrição" não seria a palavra even on its highest levels, is always adequada, pois trata-se de letras determined by the society that makes a superfície de travertino romano. its creation possible and by the mate- $\mathrm{O}$ que e um dado interessante, rial means available") (HILBERSEI- pois essa "inscrição" pode ter sido MER 1988 p. 94 traduçãonossa) retirada depois da inauguração 26. simplesmente descolando-se as 26. Evidentemente, Richard Pado- letras, e não apagada da imagem van se apoia nas interpretações da fotográfica; mas isso parece pouco arquitetura gótica de Erwin Panofsky provável, por conta do enorme inpara definir o que entende por "lógica vestimento da empresa alema visual" Voltaremos a nesse e todos os demais márvisual". Voltaremos a esse tema adi- mores para a construção do pavilante. $\quad$ hão: foram RM 187.580 (TEGETH27. Como também de sua própria OFF, 1985, p. 76), o equivalente imagem, mudando seu nome origi- U\$675.000.

nal, Maria Ludwig Michael Mies 30. Tanto é assim que tem sido (Rohe era o sobrenome da mãe que menos publicada. Mas aparece no

não é livro de Tegethoff (1985, fig. 10.21)

não é usado em Alemanha), para e no da reconstrução do pavilhão,

Ludwig Mies van der Rohe. de Solà-Morales, Cirici e Ramos (1993, p. 22). imagem retocada, se quisessem, pois a própria coleção da Hedrich-Blessing possuía também essa imagem, ${ }^{24}$ mas não o fizeram. No caso da revista, não se pode saber exatamente o porquê da escoIha. Poderiam ter usado a manipulada, pois nas referências figura a obra de Philip C. Johnson (1947), que publicou essa imagem. Quanto ao urbanista, conhecendo seu trabalho ${ }^{25}$ e sua relação com a Neue Sachlichkeit, pensamos que era mais apegado à realidade que à "lógica visual" (PADOVAN, 2002 , p. 167 , tradução nossa ${ }^{26}$ professada pelo arquiteto, o que provavelmente o levou a escolher a imagem original, que ostenta a torre de Puig i Cadafalch, pois não viu nela nada que afetasse a qualidade da obra de Mies.

Com essa manipulação de uma das fotografias para divulgação oficial do pavilhão, percebemos que Mies van der Rohe exercia total controle sobre a produção de imagens de suas obras, ${ }^{27}$ mas, diferentemente de Le Corbusier, por exemplo, que gostava de acompanhar o fotógrafo indicando as vistas do que queria registrar, Mies "tendia a controlar a fotografia após o fato, editando e alterando impressões"28 (DODDS, 2005, p. 9, tradução nossa). Alterou a vista do espelho d'água do pátio externo porque um pequeno fragmento de torre aparecia acima da cobertura, mas parece ter ido além, pois outras fotografias foram manipuladas, inclusive a da Figura 1.
No detalhe de uma imagem mais ampla, captada por Gabriel Casas i Galobardes (Figura 4) no dia da inauguração oficial do pavilhão (27 de maio de 1929), vê-se aplicada uma inscrição, ${ }^{29}$ ou antes um anúncio, logo na entrada, ao lado da escada (atrás do braço esquerdo do homem em primeiro plano, o Reichskommissar Georg von Schnitzler), informando que os mármores travertinos foram fornecidos pela empresa Köstner \& Gottschalk. Mas esse letreiro não aparece na fotografia da fachada principal (Figura 1). Talvez alguém (o próprio Mies?) tenha ordenado que se o apagasse também.

Algo parecido acontece com a fotografia oficial do lado da fachada sudoeste (Figura 5), muito menos atraente para apresentar ao grande público ou a especialistas; ${ }^{30}$ ainda assim, o fato é que foram tomadas imagens desse lado, e pelo menos uma consta do pacote da divulgação oficial. (Figura 5)

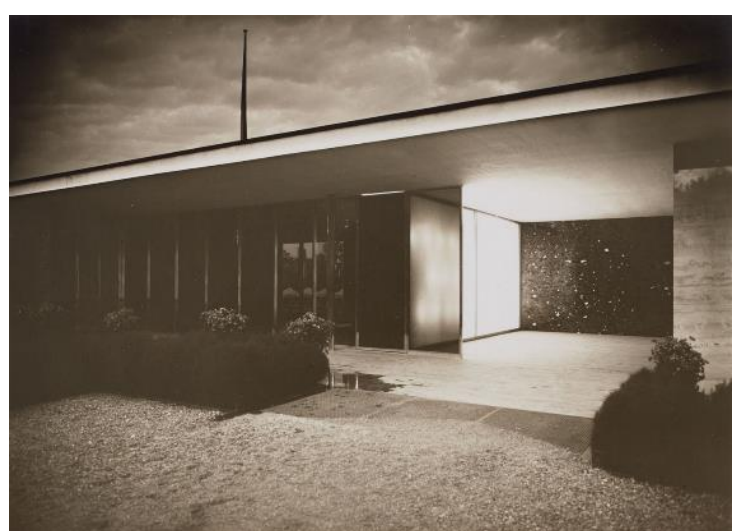

Figura 5. Imagem noturna de parte da fachada sudoeste mostrando o acesso, iluminado pelo painel de vidro fosco e a parede de mármore verde de Tinos. Berliner Bild Bericht. Fonte: The Charnel-House. 


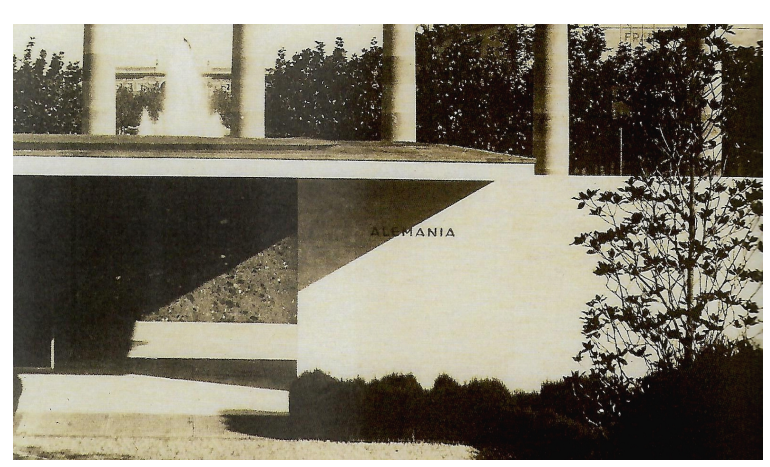

Figura 6. Detalhe de fotografia da fachada sudoeste. Autor desconhecido. Coleção da Fundació Mies van der Rohe. Fonte: Neumeyer (2018, p. 104).

31. "Habitando sin huellas". O título 34. "Das haben nun die neuen em alemão é "Spurlos wohnen" - em Architekten mit ihrem Glas und tradução livre, "vive sem deixar ras- ihrem Stahl erreicht: Sie schufen tros". Faz parte do trabalho Sombras Räume, in denen es nicht leicht is breves, publica eine Spur zu hinterlassen".

breves, publicado em duas partes, a 35 . "[...] una simple réplica de la primeira em 1929 (que não contém realidad nos dice sobre la "Spurlos") e a segunda em 1933 realidad menos que nunca". A (que o contém). O texto original está citação pode ser encontrada em: $\begin{array}{lll}\text { em Benjamin (2004). } & \text { BRECHT, Bertolt. } & \text { Der } \\ & \text { Dreigroschenprozess. } & \text { Ein }\end{array}$ 32. Esse texto é contemporâneo do soziologisches Experiment. In: pavilhão; embora tenha sido publica- KNOPF, J.; MITTENZWEI, W.; do em 1933, provavelmente foi escri- MÜLLER, K-D. (Ed.). Brecht, to perto de $1930 . \quad$ Werke, Große kommentierte 33. "Borra las huellas". Em alemão: Berliner und Frankfurter "Verwisch die Spurenl". Outra tradu- 1914-1933. Frankfut Schriften ção poderia ser "desfoca os rastros", Suhrkamp, 1990, p. 469.

ou "tira de foco os rastros". O enquadramento é uma maneira de "tirar de

foco", pois mostra apenas o que queremos ver, ficando o resto literalmen-

"remen-

e "fora do foco". Na realidade, a ex-

pressão é o estribilho (ritornelo) do

primeiro poema de Aus dem

Lesebuch für Städtebewohner (Do li-

vro de leitura para moradores da

dade) obra com dez poemas de

Bertolt Brecht, escritos entre 1921 e

1928, mas publicada em Versuche

n. 2, 1930 (uma revista editada pelo

próprio Brecht junto com a escritora

Elisabeth Hauptmann).

usjt • arq.urb • número 28 | maio - agosto de 2020
A Figura 5 apresenta um enquadramento certamente proposital, que elimina uma inscrição que indicava que o edifício era o pavilhão da Alemanha. O letreiro ("ALEMANIA"), que se percebe perfeitamente numa fotografia de autor desconhecido tomada à época (Figura 6), estava no muro à esquerda de quem entrava no pavilhão vindo do Pueblo Español, uma importante atração da exposição que se encontrava a sudoeste, subindo por uma escadaria, em patamar mais elevado. Evidentemente, existiam identificações (letreiros), como a fotografia da Figura 5 demonstra, que permitisse ao público reconhecer o edifício, sua origem (qual país representavam). Nos faz pensar que talvez existisse outro letreiro ALEMANIA na fachada nordeste (a da Figura 1), perto da escadaria, mas nunca semeIhantes sinais apareceram nas fotografias publicadas do pavilhão. Um dado curioso reforça esta insistência em eliminar a referência à nacionalidade do edifício: raramente se o denomina "Pavilhão da Alemanha". Os historiadores, os críticos, e até o público em geral, preferiram chamá-lo de Pavilhão de Barcelona

A intencionalidade da manipulação é tão evidente, que poderíamos até pensar que o título de um dos textos mais conhecidos de Walter Benjamin (1987, p. 153, tradução nossa), "Habitando sem rastros", ${ }^{31}$ pretende descrever esse pavilhão e essas fotografias. ${ }^{32}$ Seguindo o caminho de Benjamin, também se pode pensar que Mies van der Rohe obedecia à época à exigência poética de Bertolt Brecht (apud
BENJAMIN, 1987, p. 153, tradução nossa), "Apaga os rastros!". ${ }^{33}$

Sem se referir a Mies van der Rohe, Benjamin (2004, tradução nossa) poderia estar se referindo a ele quando afirma que "os novos arquitetos têm conseguido [apagar os rastros] com seu vidro e seu aço: criaram espaços onde não é fácil deixar rastros" ${ }^{34} \mathrm{E}$, graças à possibilidade seletiva do enquadramento fotográfico, as poucas marcas que escaparam podiam ser eliminadas, como de fato o foram.

Há uma intencionalidade estética e filosófica (e poderíamos até dizer ética) na construção das imagens oficiais que as fotografias exibem. Perseguese uma imagem que não é a do pavilhão real cheio de gente, com letreiros e anúncios publicitários dos produtos que o constituem e do país que os patrocina, como acontece em toda exposição. Mas isso não é novidade. Não se pode pedir à fotografia que nos fale sobre a realidade, como apontara Brecht (apud BENJAMIN, 1987, p. 81, grifo do original, tradução nossa): "uma simples réplica da realidade nos diz [hoje] sobre a realidade menos que nunca" ${ }^{35}$ Obviamente, o posicionamento do observador (o fotógrafo) no tempo e no espaço é já uma determinação desse recorte da realidade que se impõe à fotografia, mas os atos de selecionar, enquadrar e/ ou manipular impõe uma transformação maior (Verwischen). A intencionalidade do recorte, que não é senão uma supressão (na manipulação ou no 
36. Esse ponto exige um esclarecimento. Concordamos com a afirmação de Solà-Morales Rubió (1994, p. 151), para quem "o trabalho de Mies é desen-volvido, não pelas imagens, mas pelos materiais" ("Mies's work is developed, no out of images, but out of materials"), provavelmente uma crítica ao posicionamento de Quetglas (1991). Já defendíamos esse ponto de vista na nossa tese de doutorado (VÁZQUEZ RAMOS, 1993, p 89-90): "O Pavilhão é antes de mais nada arquitetura, Baukunst, que fixa o espaço através dos materiais" ("E Pabellón es ante todo arquitectura, Baukunst, que fija el espacio a través de sus materiales"), definitivamente contra a visão de Quetglas (1991) Contudo, o que fazemos aqui não é uma apre-ciação da obra construída do arquiteto, o pavilhão em si, mas de suas representações (o que elas significam e como se constroem)

37. Neumeyer se pergunta por quê, se, no julgamento de alguns críticos, a colunata jônica é - ao mesmo tempo - divisor espacial elemento de conexão, "foi excluída por Mies de todas as representações fotográficas do Pavilhão" ("were excluded by Mies from all photographic representation of the Pavilion").

usjt • arq.urb • número 28 | maio - agosto de 2020 enquadramento) - Spurlos -, impõe uma vontade comunicacional, uma mensagem está sendo enviada por meio da imagem. Nesse caso, uma imagem de conteúdo estético, de objetividade e progresso técnico. Contudo, o arquiteto não quer que essa mensagem seja enviada pela Alemanha, mas pela própria arquitetura (ou por ele mesmo). Uma arquitetura que, segundo Mies van der Rohe (2013, p. 171), é "a vontade da época que se agarra ao espaço. Viva, cambiante, nova". E ainda continua: "Conceber a forma a partir da essência [...] com os meios de nosso tempo. Esse é nosso trabalho".

No caso em tela, parece que o arquiteto está construindo a forma visível a partir da imagem manipulada, ${ }^{36}$ amparada na (falsa) objetividade da fotografia, mas com outros meios técnicos que têm mais a ver com a vontade do autor, não com os desígnios da fotografia, mas da imagem que resulta da manipulação. A representação (como imagem manipulada) é o meio real da mensagem. É, parafraseando Marshall McLuhan, a mensagem. Mas que mensagem é essa?

É importante voltar às silhuetas fantasmagóricas da colunata jônica, cujas colunas reais não aparecem em nenhuma imagem da divulgação oficial, porque, como observou Fritz Neumeyer (2018, p. 117, tradução nossa), "foram excluídas por Mies de todas as representações fotográficas do pavilhão". ${ }^{37}$ Por quê?
Voltemos à imagem. O que é evidente nessa fotografia (que até agora nenhum crítico colocou em pauta, talvez por sua obviedade)? Trata-se de uma perspectiva

Percorrendo os 20 volumes do Arquivo Mies van de Rohe, do MoMA (DREXLER, 1986; SCHULZE, 1992), percebemos que há muitas perspectivas; comparativamente, menos que plantas, mas bem mais que cortes. Entre elas, se destacam as axonometrias (ainda que não sejam as mais elaboradas, usadas antes para avaliar projetos concretos como os da casa Tugendhat, por exemplo), mas há também as cônicas (entre as quais se encontram as muito elaboradas, que incluem até colagens), prevalecendo as de ponto de fuga central. Como são essas perspectivas?

Se tomarmos as mais abstratas e, entre elas, as que se vinculam a propostas plásticas mais elaboradas, as que incluem colagens, produzidas não com a finalidade prática da comprovação da eficiência de uma forma ou de um projeto (com o é o caso das axonometrias), mas desenhadas quase como manifestos, pois seriam uma referência arquetípica à forma de entender a arquitetura (através da perspectiva) do ponto de vista particular de seus autores, as das casas com pátio dos anos 1930 seriam as adequadas para nossa análise, até porque são contemporâneas à construção do pavilhão. 


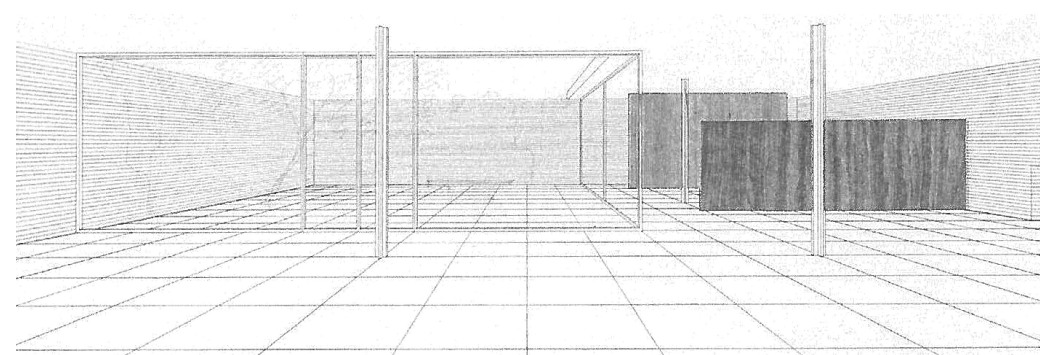

Figura 7. Casa geminada com pátio interior. 1931. Imagem digitalmente editada de uma perspectiva de Mies van der Rohe, com a finalidade de enfatizar o traçado geométrico da imagem original. Fonte: elaborado pelo autor.
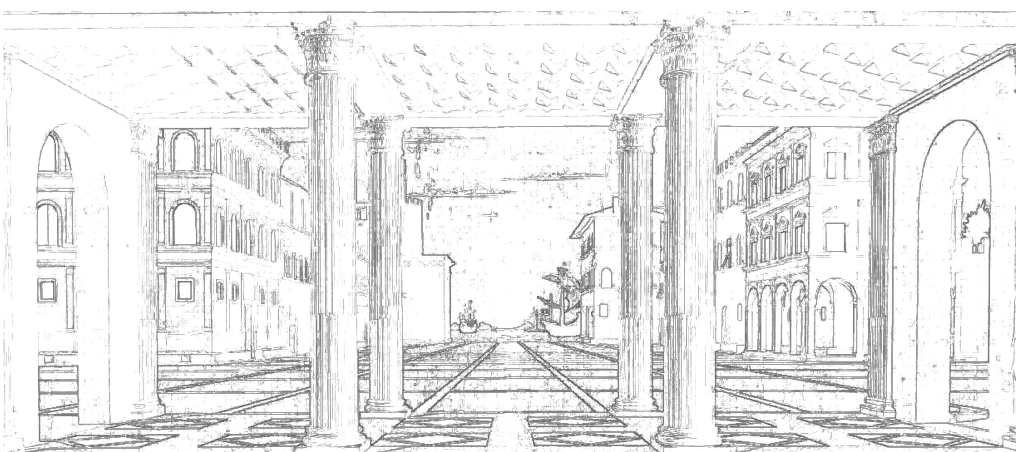

Figura 8. Città Ideale. Autor desconhecido. c. 1495. Imagem digitalmente editada, com a finalidade de enfatizar o traçado geométrico da pintura original. Fonte: elaborado pelo autor.

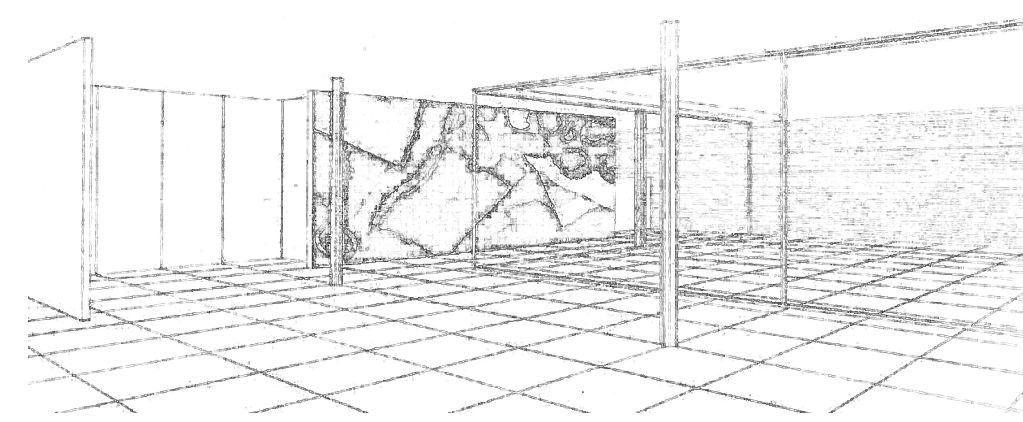

Figura 9. Casa com três pátios. 1934. Imagem digitalmente editada de uma per spectiva de Mies van der Rohe, com a finalidade de enfatizar o traçado ge ométrico da imagem original. Fonte: elaborado pelo autor.

usjt • arq.urb • número 28 | maio - agosto de 2020
Em geral, quando falamos em perspectivas desenhadas por Mies van der Rohe, a classe mais comum, como já apontávamos, é a de ponto de fuga central. Construídas seguindo o modelo clássico, aquele que vem de Leon Battista Alberti (1999, p. 216), que marca com precisão a trama do piso dando suporte à imagem, explicado graficamente no "Primeiro livro" de seu tratado De Pictura. Essa estrutura, ao mesmo tempo em que organiza a composição, evidencia o ponto de fuga e põe em ordem as figuras que integram a cena (Figura 7).

Um exemplo clássico dessa organização, com ponto de fuga central e trama de piso da qual se elevam os objetos da cena, poderia ser a veduta de uma cidade ideal, já atribuída ao arquiteto renascentista Francesco di Giorgio Martini (Figura 8) e fortemente influenciada pelas ideias de Alberti.

Certamente, Mies van der Rohe teria preferido uma fotografia que tivesse esse enquadramento (com foco único, central e ainda simétrica), mas era impossível consegui-la à época e no local, justamente pela proximidade da colunata jônica, que não permitia o distanciamento necessário para semelhante vista, a menos que as colunas fossem incluídas na imagem, como na Veduta.

Assim, chegamos às perspectivas com dois pontos de fuga. Mas, como podemos perceber na perspectiva de uma Casa com três pátios (Figura 9), também uma sofisticada imagem com colagem, Mies van der Rohe mantém, com na anterior, a organização formal e a precisão técnica, enfatizando a trama do piso. Em realidade, de um ponto de vista conceitual e também do da cena, não há diferença entre uma e outra: os recursos gráficos são os mesmos, só difere a construção gráfica da perspectiva, com um ou dois pontos de fuga (mas sempre mantendo a axialidade).

As sombras lançadas pela colunata sobre a imagem fotográfica enfatizam justamente essa marcação do chão. Certamente não é igual à demarcação da grelha de sustentação do espaço, que as linhas das juntas do piso podem delimitar (como no caso das perspectivas acima mencionadas), mas são suficientemente significativas para que possamos traçar uma analogia, uma semelhança perceptível por um olho treinado como era o do arquiteto alemão.

Mas, voltando às perspectivas com dois pontos de fuga, as de Mies van der Rohe são quase sempre centralizadas, simétricas, como as da mencionada 


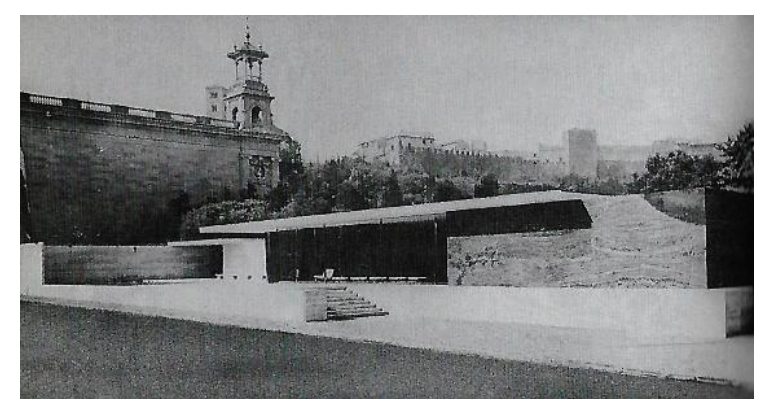

Figura 10. Vista da fachada principal (nordeste) a partir do norte. Pavilhão da Alemanha. Exposição Internacional de Barcelona, 1929. Imagem manipulada. Fonte: Quetglas (2001, p. 160)

38. As linhas paralelas ao sentido do eixo longo de um desenho (ou de um objeto), ou linhas de fluxo (streamlines), são utilizadas para enfatizar o movimento (ou o sentido aerodinâmico do objeto), as perpendiculares são utilizadas para retardá-lo ou encurtá-lo.

usjt • arq.urb • número 28 | maio - agosto de 2020
Casa com três pátios. Tendem, assim, ao equilíbrio, como querendo voltar à situação de um único ponto de fuga, que é a quintessência do classicismo e da perspectiva, além de ser o reflexo exato da "lâmina" que Alberti (1999, p. 216) apresentou em seu tratado.

A da fotografia que estamos analisando não é assim; ela apresenta uma assimetria entre os dois pontos de fuga desequilibrando os eixos, sendo o da esquerda mais acentuado que o outro. Esse tipo de perspectiva tende a dar uma sensação de movimento na direção do ponto de fuga que fica mais afastado do observador. No caso em tela, essa ideia de movimento se vê salientada pelo próprio edifício, que parece um vagão de trem que se move em direção ao grande muro do Palácio de Victória Eugênia, que serve de telão de fundo à imagem. A ideia de um vagão de trem em movimento é reforçada não só pelas proporções do edifício e sua situação, elevado do chão (acima do pódio), mas também pelo posicionamento das peças do mobiliário dentro do salão principal, que, como já havíamos comentado, se dispõem enfileiradas contra o pano de vidro do pavilhão, como se fossem assentos num vagão de trem.

pectiva simétrica. Obviamente, o muro do palácio ajuda a parar a fuga das horizontais, impondo um plano vertical de grandes dimensões, mas são as diagonais ritmadas das sombras das colunas, perpendiculares ao plano da fachada (e reforçando o sentido do ponto de fuga mais próximo), que pausam o movimento, ${ }^{38}$ levando-o a um impasse entre o ângulo do observador (o fotógrafo), que não se preocupou com essas minúcias, e o desejo do arquiteto, que estava ancorado numa lógica visual incontestável.

Mies van der Rohe não retirou as sombras porque eram favoráveis a uma compreensão clássica da composição perspéctica da imagem, assemelhando a fotografia a uma pintura (ou um desenho) renascentista, como a Veduta da Città Ideale, ou a uma de suas próprias perspectivas estilizadas, seus manifestos da racionalidade visual. Os elementos verticais, os mastros das bandeiras são também fundamentais para equilibrar essa sensação de movimento. Da mesma forma, nas perspectivas dos pátios e interiores das casas dos anos 1930 acima referidas, comparecem as colunas - comparecem também na veduta.

E há outra prova da importância que o arquiteto atriMas a imagem que temos se organiza tentando equilibrar esse movimento de fuga com as marcações do piso. Esses traços tendem a compensar o deslizamento da imagem à esquerda, dando sustentação a uma espacialidade estática, a da pers- buía a essa estrutura de sustentação e de equilíbrio visual que davam tanto as sombras das colunas como os mastros. No intento de verificar o peso gráfico e imagético desses elementos secundários (mastros, bandeiras e sombra da colunata), que 


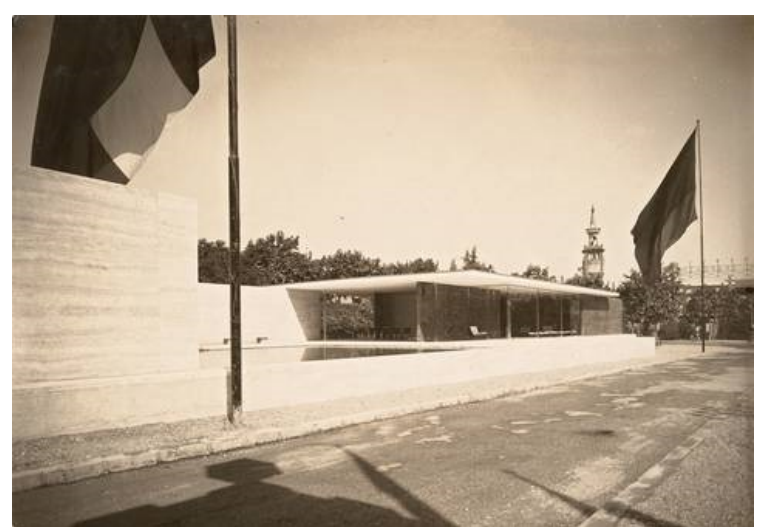

Figura 11. Vista da fachada principal (nordeste) a partir do leste. Pavilhão da Alemanha. Exposição Internacional de Barcelona, 1929. Berliner Bild-Bericht. Fonte: Artnet ([s.d.])

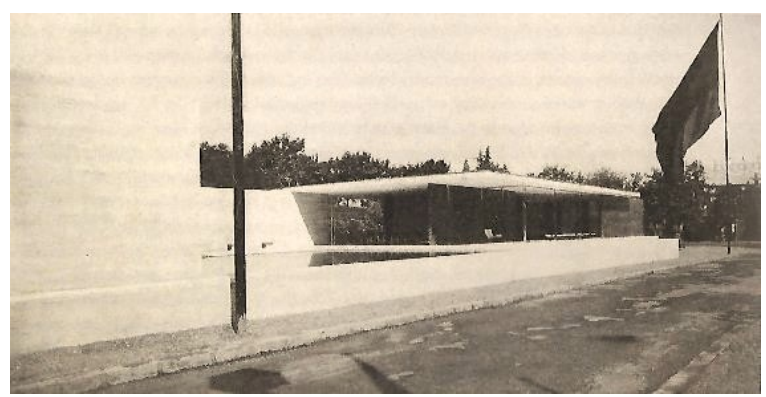

Figura 12. Vista da fachada principal a partir do leste. Pavilhão da Alemanha. Exposição Internacional de Barcelona, 1929. Imagem manipulada. Fonte: Rubió i Tuduri (1929, p. 408).

39. "Mies advirtió la carga no artigo de Rubió i Tuduri significativa de esas sombras en (1929, p. 408), mas ela aparece diagonal, corriendo por el suelo hacia também no "Álbum da Exposiel pabellón, es imaginable: lo prue ção" (LAHUERTA, 2015, p. 73) el pabellón, es imaginable: lo prueba Aparece uma imagem similar, el que las haya borrado, mas ainda mais modifica, sem manipulando las fotografías os mastros, publicada em uma oficiales". edição do Deutsche Bauzeitung, 40. De fato, só encontramos essa de setembro de 1929 (BARCEimagem no livro de Quetglas de LONA UND SEINE WEL2001, não aparece na versão do 2001, não aparece na versão do 658).

mesmo texto publicada em 1991.

41. Nos artigos de época que revisa-

mos, só encontramos essa imagem

usjt • arq.urb • número 28 | maio - agosto de 2020 não faziam parte da imagem específica do edifício, ria ser a melhor imagem para apresentar e repreMies van de Rohe aparentemente alterou a fotogra- sentar sua obra mais recente.

fia original (Figura 1) retirando o mastro mais próximo do observador (aquele que tinha a bandeira ondulante) e pintando de cinza a superfície da calçada em frente ao pavilhão, ocultando assim a sombra das colunas (Figura 10).

Josep Quetglas (2001, p.161, tradução nossa) afirma que "Mies notou a carga significativa dessas sombras em diagonal correndo pelo chão na direção do pavilhão" ${ }^{39}$ para constatar que, depois de entender esse peso significativo, Mies as apagou.

Concordamos com esse entendimento, de que o arquiteto percebia perfeitamente o peso significativo dos elementos que supostamente apagou nessa versão. No entanto, discordamos da conclusão à qual chega Quetglas, pois se realmente o arquiteto tivesse pensado que a imagem manipulada (sem sombras, mastro ou bandeira) era uma melhor representação de sua obra, não há dúvida de que essa seria a imagem da divulgação oficial, mas nunca foi. Ela não aparece em nenhum dos textos paradigmáticas sobre Mies van der Rohe, nem sequer nos de menor importância. ${ }^{40} \mathrm{Nem}$ por isso, evidentemente, essa imagem deixa de ser interessante como documento, pois traz o dado fundamental de que, aparentemente, o arquiteto pensou, sim, na importância (gráfica e significativa) dos mastros e das bandeiras, assim como na da sombra das colunas, na sua avaliação sobre qual deve-
Uma última observação seria importante. Refletimos sobre a relevância da perspectiva e sobre como a visão perspéctica de Mies pode ter influído na decisão sobre a foto representativa par excellence do pavilhão. Mas a foto da (Figura 1), afirmávamos no início, é uma vista da fachada principal do edifício, sua cara mais evidente e bela, por certo. Essa já seria uma razão suficiente para a escolha daquela fotografia como representação primordial do pavilhão. Mas ela não é a única dessa fachada que a Berliner Bild-Bericht produziu à época. Houve outra, tirada a partir do lado leste (Figura 11).

Essa imagem também foi manipulada e modificada para publicação nos artigos da época ${ }^{41}$ (Figura 12), ainda que nenhuma delas (nem a original, nem a manipulada) tenham sido utilizadas em nenhuma das publicações sobre o arquiteto que apareceram depois dos anos 1930.

Mais uma vez, a manipulação obliterou a torre da fábrica Casaramona de Puig i Cadafalch, o que era esperado, pois já havia acontecido na imagem da Figura 2. Também apagou a bandeira mais próxima do observador, mas não seu mastro, que está aí, ainda que fique estranho sem o pano da flâmula, que lhe dava um sentido mais digno e elevado; sem ele, não passa de um poste. Finalmente, podemos 
42. Esse poderia ser um bom argumento para subestimar a importância da presença das sombras no sentido dado pelo crítico espanhol, isto é, como demonstração do vanguardismo dessa prática.

43. No caso analisado por Padovan (2002, p. 167), o da estrutura metáli$\mathrm{ca}$, onde sugere que "a estrutura de aço aparente é necessária para tornar a estrutura de aço real manifesta" ("The apparent steel structure is necessary to make the actual steel structure manifest").

44. Devemos lembrar que a preocupação de Panofsky, como de Padovan, é com a arquitetura (construída); a gótica para o primeiro, a de Mies para o segundo.

usjt • arq.urb • número 28 | maio - agosto de 2020 verificar uma retalhação das sombras, que, num novo enquadramento (subindo alguns centímetros a borda inferior da imagem), eliminou mais da metade da mancha preta, retirando o peso gráfico desse detalhe que invadia a cena a partir do lado inferior esquerdo.

Em defesa dessa fotografia, poderíamos esgrimir os mesmos argumentos que demos sobre a modificação da imagem tomada do norte (Figura 1), mas eles não se aplicariam do mesmo modo. Primeiro, porque o efeito das sombras não é ritmado, nem forma uma grade de sustentação (aquela exigida pela perspectiva clássica). Pelo contrário, as sombras aparecem como uma mancha preta sem nenhum sentido compositivo (embora que útil ao argumento da invasão da janela da imagem, esgrimido por Lahuerta), ${ }^{42}$ assim, pensamos que, nesse caso, sua abolição foi positiva. Depois, porque, como acontecia na imagem tirada sobre o pódio (Figura 2), a eliminação da torre da fábrica Casaramona era previsível, ainda que a perspectiva fique sem elementos verticais de referência no fundo, uma vez que não aparece o Palácio de Victória Eugênia (que está no lado sudeste) para fechar a perspectiva e evitar a fuga visual dos objetos arquitetônicos pela direita da imagem, embora seja evidente que a pequena torre não seria capaz de tal proeza.

Como se pode notar, essa fotografia não é uma perspectiva no mesmo sentido em que o é a tirada do norte. Ainda que a imagem seja perspectivada (como toda fotografia), essa não é uma perspectiva porque não apresenta os elementos de uma lógica visual que lhe dariam um sentido perspéctico, quais sejam: a organização gráfica dos elementos da base, que reforçam o traçado perspectivado; a organização dos elementos verticais, que são capazes de equilibrar os horizontais em fuga; e, não menos importantes, os anteparos, ou pano de fundo, que a situam espacialmente. Não é suficiente termos uma fotografia para apreciarmos uma perspectiva. A fotografia tem de estar montada segundo suas leis, e mesmo as leis da ótica (que igualam câmeras e perspectivas) são insuficientes, porque as perspectivas seguem desígnios gráficos (as marcas de sua construção) enquanto as imagens fotográficas não precisam deles nem os adotam.

Assim, devemos voltar à lógica visual. Não só às definições de Erwin Panofsky (1951), que é a fonte de Richard Padovan (2002) para explicar a atitude de Mies van der Rohe com relação aos desígnios que se revela em suas atitudes projetuais, ${ }^{43}$ mas também a uma interpretação mais ajustada ao problema das representações, ${ }^{44}$ que é o tema que nos interessa aqui.

Henri Lefebvre (1991, p. 258) percebe na formulação panofskiana a homologia entre filosofia (como visão de mundo) e arquitetura (ainda que "dissociada de todo conteúdo e contexto"). Do mesmo modo, ambos identificam a possibilidade de uma relação 
direta entre o que se pensa (sobre o mundo) e o que se faz (no mundo) apontada por Panofsky, mas também poderíamos entender o postulado do historiador da arte, de uma forma ampliada, remetendoo àquilo que se oferece à visão, ao que se deixa ver. Mas, o que se vê no caso que analisamos (o das fotografias do pavilhão)? Vê-se o edifício, mas se vê também a imagem do edifício - uma representação.

Lefebvre desqualifica a proposta de Panofsky porque não vê que aponte uma relação precisa entre a produção arquitetônica e o contexto histórico (social, político e mesmo cultural) em que se insere a arquitetura, o que para Lefebvre é fundamental. Entretanto, esse acertado questionamento não parece aplicável ao tema das representações, pois, há mais de 500 anos, arquitetos desenham usando praticamente os mesmos recursos gráficos (plantas, elevações, cortes e perspectivas), independentemente das condicionantes do contexto histórico.

Os sistemas representacionais da arquitetura (tanto o diédrico como o perspéctico) têm suas próprias regras, e ainda que algumas convenções tenham mudado, como as notações, por exemplo, em geral, as estruturas conceituais que regem o sistema gráfico e a lógica visual de suas interpretações permanecem as mesmas. Essas estruturas são necessariamente consensuais, compartilhadas com os outros artistas que adotam esses sistemas para comunicar suas intenções (não só formais, mas espa- ciais e, sobretudo, conceituais). Essas convenções demandam uma concordância entre o que se desenha e o que se percebe como imagem, amparadas numa lógica visual (interpretação consensual e técnica) que se soma à lógica visual panofskiana da razão (e aqui esse termo é importante) para a construção formal, pois é portadora do entendimento humano sobre o mundo, da Weltanschauung do autor através da proposta representacional.

Assim sendo, ainda que a lógica visual que preocupa Panofsky - e Padovan - seja a da arquitetura construída, num entendimento ampliado mas conceitualmente sólido, poderíamos aceitar que o objetivo de dar a entender (e apreciar) a lógica visual deve estar no objeto que se vê ou analisa (seja o da arquitetura ou o da representação).

No nosso caso, o objeto percebido não seria o paviIhão (o prédio realmente edificado em 1929), mas suas representações: as imagens fotográficas. 0 pavilhão (a construção), como todo o entorno (visível ou oculto, manipulado ou aparentemente real, objetivo), é simplesmente parte da composição da imagem fotográfica, que deve ser tratada (como toda representação) como um objeto outro, que não é, repetimos, a construção, mas que tampouco, como veremos, é a fotografia (réplica da realidade).

Mies van der Rohe não era um artista familiarizado com o métier da fotografia, ainda que o fosse com as imagens fotográficas, como sabemos por seu 
45. Ludwig Mies trabalhou no escritório do arquiteto Peter Behrens de 1908 a 1913. Começou como desenhista, mas galgou diferentes posições, chegando a ser diretor de obras (projeto da embaixada alemã em São Petersburgo) (SCHULZE, 1986, p. 59).

46. A lógica visual no sentido estritamente panofskiano

47.“[...] his perspective also cannot be explained without taking into account his sustained and continuous intellectual exchange with art, artists, and art history".

usjt • arq.urb • número 28 | maio - agosto de 2020 constante trabalho com fotomontagens. A prática da fotografia, como já mencionamos, chegou tardíssimo à Bauhaus, e foi pelas mãos de Hannes Meyer (e não pelas de Mies, muito menos pelas de Gropius). Mas Mies era um artista sensível às questões formais e, sobretudo, às da representação. Usava técnicas que provinham de variadas fontes artísticas, do expressionismo ao neoplasticismo e ainda do construtivismo, da nova objetividade e até do Dadá, mas não tinha nenhuma vinculação com o futurismo (e sua preocupação obsessiva com o movimento e com a velocidade). Tinha, e isso é muito importante, uma sólida formação como desenhista, profissão que o ajudou a entrar no mundo da arquitetura. Lembremos que não era arquiteto titulado, mas se fez arquiteto pela prática e pela vivência de escritório, e nada menos que no escritório de Peter Behrens. ${ }^{55}$ Assim, por meio de um aprendizado prático (e clássico) na Schinkelschule de Behrens seguido de uma compreensão precoce da importância da vanguarda, sua produção e suas técnicas de reprodução (especialmente as visuais), tanto para o desenvolvimento da arquitetura como para o da arte, o levaram a uma refinada experimentação da arquitetura que se fez através do desenho.

Mies van der Rohe confiava no poder da representação da forma, na imagem, como comprovam seus projetos utópicos do começo dos anos 1920, que vão do expressionismo dos arranha-céus de cristal (1921 e 1922) ao neoplasticismo da Casa de
Campo de Tijolos (1923-24), mas também seus trabalhos com fotomontagens e colagens (BEITIN; EIERMANN; FRANZEN, 2017), que começaram com seu projeto para o Monumento a Bismarck (1910), seguiram com as propostas para Friedrichstraße (1921) e se multiplicaram por toda a sua vida. Confiava nos desenhos como portadores de mensagens cristalinos e verdadeiros. ${ }^{56}$ Confiava nos desenhos que podia controlar e que tinham sentido na sua Weltanschauung, sua cosmovisão. Mas, como afirma o curador do MoMA Martino Stierli (2017, p. 139, tradução nossa), "sua visão de mundo tampouco pode ser explicada sem ter em conta seu contínuo e permanente intercâmbio intelectual com a arte, os artistas e a história da arte". ${ }^{57}$ Eram artistas plásticos que entendiam de perspectiva (pensamos em Theo Van Doesburg) e historiadores da arte que, como Panofsky, Heinrich Wölfflin, ou Aby Warburg, que defendiam e entendiam o valor da construção das imagens.

Por tudo, se realmente queremos nos aproximar, ainda que por especulação, das razões que levaram Mies van der Rohe a definir a imagem da (Figura 1) (ou qualquer outra das que discutimos aqui) como sendo capaz de explicar (dar conta e apresentar) seu pavilhão, há que analisá-la graficamente, como se se tratasse de uma perspectiva. Por quê? Porque, depois das análises feitas, é evidente que interessava a Mies uma determinada forma de apresentar sua obra que não era a asséptica captação fotográfica (a inoperante réplica da realidade), 
48. Muito defendida pelos críticos espanhóis, mas não só.

usjt • arq.urb • número 28 | maio - agosto de 2020 a que resultava do olho do fotógrafo (um técnico que podia ser manipulado, e não um artista) e muito menos a que se referia à específica localização de seu pavilhão em Barcelona. ${ }^{58}$

Sendo que o objeto é a imagem, e que não é relevante o fato de que seja uma fotografia (pois foram manipuladas), nossa interpretação deve recair sobre seus aspectos formais como perspectiva, como fato gráfico. Assim, podemos entender melhor a inclusão (ou a exclusão) dos elementos que com põem cada uma dessas imagens, ou as imagens mesmas.

Diante do sistema de representação perspectivo cônico e caso se queira apresentar uma imagem equilibrada ou estática, ancorada no chão, que precisa ter sua marcação expressa (numa grade de piso), é preciso incluir elementos verticais para equilibrar as fugas que são produzidas pela própria perspectiva. Quando a perspectiva tem dois pontos de fuga e estes são assimétricos com relação ao observador, só os elementos verticais são capazes de sustentar o equilíbrio. Mies sabia perfeitamente de tudo isso, e suas perspectivas cônicas o demonstram. Outro aspecto que ele percebia bem era que, na perspectiva clássica (renascentista), a demarcação do piso (a grade) era fundamental para se entender não só o próprio sistema perspectivo (e, portanto, um entendimento por parte do observador), mas também o sistema espacial onde se insere a cena.
Mies van der Rohe era um bom comunicador, dominava as técnicas tradicionais (e também as experimentais) de representação da arquitetura, entendia os princípios que regiam esse tipo de imagem (da mesma forma que seus pares: arquitetos, artistas, críticos e historiadores da arte, a quem se dirigiam as imagens) e por essas razões foi capaz de desenvolver uma lógica visual precisa. Essa percepção Ihe permitiu entender que precisava intervir nas imagens fotográficas, se realmente queria pas-

sar a mensagem certa de sua obra para seus pares: a de uma arquitetura sem impurezas (ideal?), sem rastros (Spurlos), objetiva (Sachlich), mas radiante (com o sol iluminando frontalmente seus muros claros). Só as imagens manipuladas permitiriam tal depuração moderna da arquitetura. Tinha que poder decidir sobre qual imagem servia a seus interesses plásticos, mas também éticos e estéticos (e, incluso, de propaganda). As representações não representam o mundo físico (construído); são, de fato, manifestações do pensamento cuja lógica é expressiva, não réplicas da realidade. Não perseguem a verdade das coisas, mas, parafraseando Platão, procuram a que aportam as ideias às coisas.

\section{Referências}

ALBERTI, León Bautista. Los tres libros de la pintura. In: $\mathrm{VINCl}$, Leonardo. El tratado de la pintura y los tres Libros que sobre el mismo arte escribió León Bautista Alberti. Barcelona: Alta Fulla, 1999. p. 197266. 
ARTNET. Past Auction. Disponivel em: <http:// www.artnet.com/artists/berliner-bild-bericht-andludwig-mies-van-der-rohe/barcelona-pavillon-frontside-seen-from-the-YC1g_jvYLZkZ4gV1oRA4jg2>. Acesso em: 11 abr. 2020.

BARCELONA UND SEINE WELTAUSSTELLUNG. Deutsche Bauzeitung, Berlim, n. 77, p. 657-659, 25 set. 1929.

BAUHAUS100. Lilly Reich: 1932-1933 Bauhaus maste [sic]. Disponível em: <https://www.bauhaus100.com/ the-bauhaus/people/masters-and-teachers/illy-reich/>. Acesso em: 11 abr. 2020.

BEITIN, Andreas F.; EIERMANN, Wolf; FRANZEN, Brigitte. Mies van der Rohe: Montage, Collage. Köln, DE: Walther König, 2017.

BENJAMIN, Walter. Spurlos wohnen. BENJAMIN, Walter. In: Illuminationen: Ausgewählte Schriften I. Textlog $2004 . \quad$ Disponivel em: $<$ https://www.textlog.de/benjamin-spurlos-wohnen-

kurze-schatten.html>. Acesso em: 11 abr. 2020.

Taurus, 1987.

\section{Discursos interrumpidos I. Madrid:}

BIER, Justus. Mies van der Rohes Reichspavillon in Barcelona. Die Form - Zeitschrift Für gestaltende Arbeit, v. 4, n. 16, p. 423-430, 15 ago. 1929.
BONTA, Juan Pablo. Sistemas de significación en arquitectura. Barcelona: Gustavo Gili, 1977.

CARTER, Peter. Mies van der Rohe at work. London: Phaidon, 1999.

DEUTSCHLAND IN BARCELONA. Das Neue Berlin, Monatshefte für Probleme der Großstadt, Berlin, n. 9, p. 188, 1929.

DODDS, George. Building Desire: On the Barcelona Pavilion. London/New York: Routledge, 2005.

DREXLER, Arthur. (Ed.). The Mies van der Rohe Archive. New York: The Museum of Modern Art, 1986. 4 v.

GUEREÑU, Laura Martínez. Mies, Barcelona and the Bauhaus: The Pavilion as a $16,000 \mathrm{~m}^{2}$ Anteroom to the Exposition. In: LAHUERTA, Juan José; MARÍN, Celia (Org.). Mies van der Rohe: Barcelona, 1929. Barcelona: Fundació Mies van der Rohe Barcelona / Tenov, 2018. p. 44-77.

HILBERSEIMER, Ludwig. The Art of Architecture. In: POMMER, Richard; SPAETH, David; HARRINGTON, Kevin. In the Shadow of Mies: Ludwig Hilberseimer: Architect, Educator and Urban Planner. Chicago: The Art Institute of Chicago / Rizzoli, 1988. p. 94-99.

JOHNSON, Philip. C. Mies van der Rohe. New York: The Museum of Modern Art, 1947. 
LAHUERTA, Juan José. Photography or life popular

Mies. Columns of Smoke. Barcelona: Tenov, 2015. v. 1.

LANGE, Christiane. Ludwig Mies van der Rohe \& Lilly Reich: Furniture and Interiors. Ostfildern: Hatje Cantz, 2006.

LEFEBVRE, Henri. The Production of Space. Oxford, GB/Cambridge, US: Blackwell, 1991.

MERTINS, Detlef. Mies. New York: Phaidon, 2014.

MIES VAN DER ROHE, Ludwig. Aforismo. In: VÁZQUEZ RAMOS, Fernando Guillermo. Mies van der Rohe define Arquitetura: aforismo, 1923. Uma tradução e reflexões sobre os significados do preceito. Arq.urb, São Paulo, n. 10, p. 169-171, 2013.

MIES VAN DER ROHE: European works. Architectural Monograph, London / New York: Academy / Martin's Press, n. 11, 1986. Número especial.

MIES VAN DER ROHE: Less is more. Moins est plus. L'Architecture D'Aujopurd'hui, Paris, v. 29,

n. 79 , set. 1958. Número especial.
NEUMEYER, Fritz. The secret life of columns. In: LAHUERTA, Juan José; MARÍN, Celia (Org.). Mies van der Rohe: Barcelona, 1929. Barcelona: Fundació Mies van der Rohe Barcelona / Tenov, 2018. p. 105123.

NEUMEYER, Fritz. Mies van der Rohe: la palabra sin artificio, reflexiones sobre arquitectura 1922 / 1968. Madrid: El Croquis, 1995.

PADOVAN, Richard. Towards universality: Le Corbusier, Mies and De Stijl. London / New York: Routledge, 2002.

PANOFSKY, Erwin. Gothic Architecture and Scholasticism: an inquiry into the analogy or the arts, philosophy, and the religion in the Middle Ages. New York: Meridian New American, 1951.

QUETGLAS, Josep. El horror cristalizado: imágenes del Pabellón de Alemania de Mies van der Rohe. Barcelona: Actar, 2001.

Der Gläserne Schrecken: imágenes del Pabellón de Alemania. Mies van der Rohe. Montreal: Section b, 1991.

ROVIRA, Josep M. Barcelona. Berlin. 1929. In: ROVIRA, Josep M.; CASALS, Lluis. Reflections: Mies van der Rohe Pavilion. Barcelona: Triangle Postals, 2002. p. 48-71. 
RUBIÓ I TUDURÍ, Nicolás M. Le Pavillon de l'Allemagne à l'Exposition de Barcelone para Mies van der Rohe. Cahiers d'Art, Paris, n. 8-9, p. 408-410, 1929.

SCHULZE, Franz. (Ed.). The Mies van der Rohe Archive. New York: The Museum of Modern Art, 1992. v. 5-20.

SCHULZE, Franz. Mies van der Rohe: una biografía crítica. Madrid: Hermann Blume, 1986.

SOLÀ-MORALES RUBIÓ, Ignasi. Mies van der Rohe and Minimalism. In: MERTINS, D. (Ed.). The presence of Mies. New York: Princeton Architectural, 1994. p. 149-155.

SOLÀ-MORALES, Ignasi; CIRICl, Cristina; RAMOS, Fernando. Mies van der Rohe: el Pabellón de Barcelona. Barcelona: Gustavo Gili, 1993.

SPEYER, A. James. Mies van der Rohe. Chicago: The Art Institute of Chicago, 1968.

STIERLI, Martino. The visuality of space and the space of vision: on Mies van der Rohe's late photocollages. In: BEITIN, A. et al. (Ed.). Mies van der Rohe. Montage. Collage. Achen, DE / London: Ludwig Forum für Internationale Kunst / Museum Georg Schäfer Schweinfurt / Koenig, 2017. p. 126-139.
TEGETHOFF, Wolf. From obscurity to maturity: Mies van der Rohe's breakthrough to modernism. In: SCHULZE, Franz. (Ed.). Mies van der Rohe: critical essays. New York: The Museum of Modern Art / The MIT Press, 1989. p. 28-94.

TEGETHOFF, Wolf. Mies van der Rohe: The Villas and Country Houses. New York: The Museum of Modern Art, 1985.

THE CHARNEL-HOUSE. From Bauhaus to Beinhaus. Disponivel em: <https://thecharnelhouse.org/ 2016/12/18/mies-van-der-rohe/berliner-bild-berichtdeutsche-pavillon-weltausstellung-barcelona-beinacht/>. Acesso em: 11 abr. 2020.

TORRENT, Rosa María Subirana. El Pabellón Alemán de Barcelona de Mies van der Rohe, 19291986. Barcelona: Fundación Pública del Pabellón Alemán de Barcelona de Mies van der Rohe, 1987.

VÁZQUEZ RAMOS, Fernando Guillermo. La actitud creativa en Mies van der Rohe: tesis sobre las interpretaciones del pasado en la modernidad. Tese (Doutorado em Arquitetura) - Escuela Técnica Superior de Arquitectura de Madrid, Universidad Politécnica de Madrid, Madri, 1993. 2 v.

WARE, Katherine C. La fotografía en al Bauhaus. In: FIEDLER, Jeannine; FEIERABEND, Peter. (Ed.). Bauhaus. Colonia, DE: Könemann, 1999. p. 506-529. 